\begin{tabular}{|c|c|}
\hline $\begin{array}{l}\text { ÇÜTAD } \\
\text { Çukurova Üniversitesi } \\
\text { Türkoloji Araștırmaları Dergisi }\end{array}$ & $\begin{array}{l}\text { Cilt 4, Sayı } 2 \\
\text { Aralık } 2019\end{array}$ \\
\hline $\begin{array}{l}\text { ISSN: 2587-1900 } \\
\text { E-ISSN: 2548-0979 }\end{array}$ & $\begin{array}{l}\text { Geliş Tarihi: } 16.09 .2019 \\
\text { Kabul Tarihi: } 21.11 .2019\end{array}$ \\
\hline \multicolumn{2}{|c|}{$\begin{array}{l}\text { Makale Künyesi (Araştırma): Sıdıkova, Ç. (2019). Kutadgu Bilig } \\
\text { eserindeki görgü kurallarının Kırgız atasözlerinde görünümü. Çukurova } \\
\text { Üniversitesi Türkoloji Araştırmaları Dergisi. } 4 \text { (2), 298-314. }\end{array}$} \\
\hline
\end{tabular}

\title{
KUTADGU BİLİG ESERİNDEKİ GÖRGÜ KURALLARININ KIRGIZ ATASÖZLERINDE GÖRÜNÜMÜ
}

\section{ÖZET}

Çolpon T. SIDIKOVA ${ }^{1}$

Bu çalışmada Kutadgu Bilig'de yer alan görgü kurallarının Kırgız atasözlerinde işlenişinin karşılaştırması yapılarak aradaki ortak genetik bağlar ortaya konacaktır. Kutadgu Bilig, tüm Türk halklarının ilk klasik eserlerinden biridir. Eser, ortak Türk felsefesine ait olan temel insanî değerleri yansıtmaktadır. Türk folklorunun bir parçası olan Kırgız atasözlerinin Kutadgu Bilig eserinde yansıtılan görgü kurallarıyla benzerlik arz ettiği söylenebilir. Eser, temsili karakterlerle ağırlıklı olarak siyaset, yönetim, adalet gibi kavramlar üzerinde yoğunlaşmış gibi gözükse de esas insanı ve insanla ilgili her şeyi içinde barındırmaktadır. Kırgız folklorunda işlenen insanî değerlerin, Kutadgu Bilig'deki değerler ile birebir aynı olduğu söylenebilir. Makalede, Kutadgu Bilig ve Kırgız atasözlerinde yansitılan etik davranış standartları incelenir ve benzerlikleri tanımlanmıştır.

Anahtar kelimeler: Atasözleri ve deyimler, genetik bağlar, insani değerler, görgü kuralları, folklor.

\section{ETHICAL IDEAS OF THE KUTADGU BILIG IN KYRGYZ PROVERBS}

\begin{abstract}
The given article provides a comparative analysis of the ethical ideas formulated in the poem "Kutadgu Bilig” by Jusup Balasagyn with Kyrgyz proverbs, and the genetic relationships between them are revealed. The poem "Kutadgu bilig” is one of the first Turkic classical works. It has reflected the common Turkic philosophy, the main ideas of which are universal human values. Kyrgyz proverbs and sayings, as
\end{abstract}

1 Kırgızistan-Türkiye Manas Üniversitesi, Edebiyat Fakültesi, Mütercim Tercümanlı Bölümü, Doç. Dr. cholpon.sydykova@manas.edu.kg, sydykovacholpon6@gmail.com https://orcid.org/0000-0001-7614-8333 
part of the Turkic folklore, have similarities with the moral and ethical ideas, which are reflected in the poem by Jusup Balasagyn. This work is saturated with wise proverbs reflecting the principles of morality, which later formed the basis for the formation and development of the spiritual world, the national character of all Turkic-speaking peoples, including the Kyrgyz people too. The analysis confirms the genetic relationship between the ideas embodied in the "Kutadgu bilig" poem and Kyrgyz proverbs.

Keywords: Proverbs and sayings, genetic link, human values, ethical ideas, folklore.

\section{GíRiș}

Yusuf Has Hacib'in kaleme aldığı Kutadgu Bilig'i, Türk halklarının felsefi ve eğitici fikirlerinin yansıtıldığı Türk kültürünün XI. yüzyıldaki büyük bir abidesidir. Eserde geçen esas konular daha çok Orta Çă̆ Türk kültür yaşamını, düşünce algılayışını yansıtır (Kakeev, 2012, s. 78). Ahlaki ve eğitici açıdan büyük öneme sahip olan eser, içerisinde sıfat (epithet), mecaz (metaphor), karşılaştırma ve alegori gibi çeşitli söz sanatlarını barındırmaktadır. Yusuf Has Hacib'in eserinde folklor motiflerinin yanı sıra Türk halklarının sözlü halk sanatı ve kadim Türk halk felsefesini yansıtan eğitim ilkelerini içeren atasözlerine geniş ölçüde yer verilmiştir. Yusuf Has Hacib'in eseri L. F. Ivanova tarafindan halk pedagojisi fikirlerine dayanan bir eser olarak nitelendirilmektedir:

Yüzyıllar ve belki de bin yıllar boyunca halkın zamanla sınanmış bilgeliğini anlama, koruma ve gelecek nesillere aktarma meselesi üzerinde düşünülmüştür. İnsanlar çok eski çağlardan beri yüksek ahlâkî değer ve niteliklere dayanan kendi eğitim sistemini oluşturarak gelecek kuşakları pratik bilgilerle gerçek hayata hazırlamışlardır. Bu eser, insanın sosyalleşmesi açısından günümüzde de güncelliğini koruyan birçok eğitici fikir, usul ve etkileme yöntemini içermektedir. Halksn iyi kalplilik ile güzellik idealleri gibi manevî zenginlikleri ve aile, soy ile kabileye olan ilişkisi sonuçta onun millet ile uluslararası ilişkilere karşı ahlaki ve estetik tutumunu yansitmaktadır (İvanova, 2003).

Kutadgu Bilig'de ahlaki konulara son derece ayrıntılı bir şekilde yer verildiğinden dolayı S. A. Mukasov söz konusu eserin ahlaki ve eğitici yönü üzerinde durmaktadır. Mukasov'a göre insanî ve yüce idealleri yansıtan en önemli görgü kuralları ve ahlak ilkeleri, halk rivayetleri, masallar, atasözleri ve deyimlerde gösterilmektedir. Yazar, folklorda yansıtılan görgü kurallar halkın iyilik, kötülük, mutluluk, adalet gibi konularla ilgili görüşlerini ifade edeceğini belirtir 
(Mukasov, 2000). Böylelikle halkın aklına kazınan mevzubahis görgü kuralları, toplumda insanların ilişkilerini yönlendiren ilkeler ve kurallar hâline gelmiştir. Kutadgu Bilig'de, Türk dünyasının ulusal karakteri ile maneviyatının daha da gelişmesini etkileyerek kadim Türk kültürünü temsil edenlerin bilinci ve geleneklerine derin kök salan ahlaki ve etik kurallar kaleme alınmıştır (Sıdıkova, 2016, s. 181). Ayrıca şunu belirtmek gerekir ki Kutadgu Bilig eserindeki temel ahlaki ilkeler ortak insani değerleri yansıtarak farklı halkların felsefesi ile folklorunda yer alan görgü kurallarıyla örtüşmektedir.

Kutadgu Bilig, zaman içerisinde diğer Türk lehçelerinde benimsenerek kullanılmaya başlayan mükemmel denilecek kadar üslupla yazılmış eşsiz bir edebî eserdir. Bilim adamlarının çoğu, söz konusu edebî abidenin yalnızca bir Türk boyunun değil tüm Türk boylarının ortak kültürel zenginliği olduğunu öne sürmektedirler.

A. Aliyev yaptığı çalışmasında bu eser ile ilgili bazı Kırgız bilim adamlarının görüşlerini esas alarak Yusuf Has Hacib'in bu eserinin diğer Türk lehçelerine nazaran daha çok Kırgızcaya yakın bir dilde yazılmış olduğunu ortaya koymaktadır (Aliev, 2016, s. 136). Bundan dolayı Kutadgu Bilig'in adının bile Kırgızca çevirileriyle daha uyumlu olduğunu söylemek mümkündür: Kut Aluuçu Bilim, Kut Bilim, Kuttuu Bilim, Kut Daarıtar Bilim. Ayrıca ünlü Kırgız bilim adamı K. Toktonaliyev de bu büyük eserin çevirisi ile ilgili kendi görüşünü ortaya koymaktadır. Yazarın önerdiği tercüme de (Kutadgu Bilig / Kut Attuu Bilik) eserin orijinal adıyla gayet uyumludur. Söz konusu eserin orijinal başlığı Kırgızcaya çevrilen örneklerine hem ses hem de anlam bakımından son derece yakındır. "Kut" kelimesi "mutluluk" ve "uğur" anlamına geliyorsa, ondan türeyen "Kuttuu" sözcügü "kutsal", "bereketli" ve "mutlu" demektir (Toktonaliev, 2016). Kırgızcada "kut” kelimesi ve onun türevleri kalıp söz niteliğinde konuşmada oldukça yaygın bir şekilde yer almaktadır. Örneğin, Kut bolsun!, Kut kılsın!, Kuttuu bolsun! (Kutlu olsun), Kut ornosun! (Mutluluk ve bereket olsun), Kuttuktaym! (Kutluyorum), Kut kaçtı (Mutluluk terk etti), Kança üygö but kirse, oşonço kut kiret (Eve ne kadar insan gelirse,o kadar mutluluk olur), Kuttuu üydön kuru çıkpayt (Bereketli evden eli boş çıkılmaz) vb. Böylece Kırgızcada "kut” kelimesi eski zamanlardan beri mutluluk, bereket, uğur gibi ancak olumlu anlam taşımaktadır (Kozubekov, 1993, s. 7). Z. Eraliyev de Kutadgu Bilig'in yazıldığı dilin bugünkü Türk halklarının diline çok yakın olduğunu belirtmekle aynı zamanda bugünkü Kırgızcanın da esas başlangıcını oluşturduğunu dile getirmiştir (Jamal ve Kafkasyalı, 2016, s. 68-69). 


\section{YÖNTEM}

Kutadgu Bilig, tüm Türk halklarının ilk klasik eserlerinden biridir. Eser, insani değerleri esas alan ortak Türk felsefesini yansıtmaktadır. Kırgız atasözleri, Türk folklorunun bir parçası olarak Kutadgu Bilig'de yansıtılan görgü kurallarıyla benzerlik arz ettiği söylenebilir. Burada atasözlerinin Kırgız halkının tarihsel, kültürel, millî maddi ve manevi değerlerini içerip, asırdan asra nesilden nesle aktarmadaki yeri ve önemi dikkate alındı. Kırgız folklorunda işlenen insanlık değerleri, Kutadgu Bilig eserindeki değerler ile karşılaştırılacaktır. Çalışmada izlenilen yol öncelikle Kutadgu Bilig eserinin Türkçe çevirileri ve Kırgız atasözleri ile ilgili kaynakları tarama yoluyla benzerlik arz eden örnekler çıkartılacak ve incelenecektir.

\section{BULGULAR VE YORUMLAR}

\section{Kutadgu Bilig Eseri ile Kırgız Atasözlerindeki Ahlaki ve Manevi Değerler}

Kırgız folklorunda insan davranışının ahlaki değerlendirmesi hakkındaki konuya çok önem verilmektedir. Genel olarak, insanların davranışları "kötü” veya "iyi” olarak değerlendirilir. İnsanlığın ahlaki değerlerini korumayı özellikle Kırgız ozan ve halk şairleri görev edinmiş, Kırgız ozanları hayatta, toplumda ve hatta etrafta olup biten her şeyi olduğu gibi aktarmaya ve şiirlerinde yansitmaya çalışmışlardır. Şiirlerinde başlıca güzellik ve çirkinlik, aşk ve nefret, mutluluk ve mutsuzluk, üzüntü ve öfke, yücelik ve alçaklık, komik ve trajik gibi birbirine zıt konular işlenmiştir. Kutadgu Bilig Türk halklarının edebiyatında büyük öneme sahip olmuş, Kırgız atasözleri de Kutadgu Bilig'in felsefi fikirlerine karşılık gelip, Kırgızların ahlaki değerlerini yansıtmıştır.

Eserdeki felsefi düşüncelere uygun olan Kırgız atasözleri halkın ahlaki değerlerini kısa ve öz bir biçimde yansıtmıştır. Zira atasözlerinde halkın değer yönelimleri, zihniyeti, yani düşünce yapısı, tutumu, dünya görüşü, psikolojisi ve ruhsal durumu hem bireysel hem de toplumsal düzeyde en açık şekilde yansıtılmıştır (Ter-Minasova, 2000, s. 146).

\section{1. Hayat, Ölüm, Namus, Zenginlik}

Kırgız halk bilimi ürünlerindeki insan yaşamının değerlendirilmesiyle ilgili kriterler, Kutadgu Bilig'de anlatılan felsefi fikirlere benzerlik göstermektedir. İnsan karakterinin en önemli değerleri olarak kabul edilen namus ile şerefi koruma hususu, aşağıdaki Kırgız atasözlerinde en iyi şekilde yansıtılmıştır: 
Abiyirdi caşından sakta (Şerefini gençken koru).

Cakşının özü ölsö da, sözü ölböyt (İyi bir insan ölürse bile söylediği söz sonsuza dek yaşar).

Büyük düşünür Yusuf Has Hacib dünyanın faniliğinden bahsederek insanın bu dünyada bir misafir olduğunu ve günü geldiğinde ayrılmak zorunda kalacağını dile getirmektedir.

"Ölüm bir tengiz ol uçı yok tüpi

Baka körse yetrü tüpi yok batıg” (Arat, 1947, s. 131).

1140. Ölüm uçsuz-bucaksız bir denizdir; iyice dikkat edersen, dipsiz bir çukurdur (Arat 1959, s. 93).

"Toguglt tirigler ölümke sanı

Ölümke toguglı tirig kim kanı" (Arat, 1947, s. 137).

1201. Doğan her canliyı ölecek bil; ölmek için doğanlardan diri kalan hani, kimvar (Arat, 1959, s. 97).

"Tüşün ol bu dünya keligi keçer

Yigen yil büke teg yir erken açar" (Arat, 1947, s. 137)

1202. Bu dünya bir konak yeridir, gelen geçer; o her şeyi yiyen büyük bir ejderha gibi, yedikçe acıkır (Arat, 1959, s. 97).

"Keçigli turur dünya keçti sakın

Keligli ölüm utru keldi sakin” (Arat, 1947, s. 164).

1465. Bu dünya geçicidir, sen onu şimdiden geçti bil; ölüm muhakkak gelecektir, sen onu karşına artık geldi bil (Arat, 1959, s. 114).

"Kapug açtı dünya takı bir kapug

Ölüm kapgı açlur kirur halk kamug” (Arat, 1947, s. 355).

3531. Bir kapı açıldı - dünya kapısı; bir kapı daha açılır, o kapı ölüm kapisidir ve her kes oraya girer (Arat, 1959, s. 251).

Kutadgu Bilig eserinin yazarına göre para ve zenginlik gelip geçici şeylerdir:

"Ölülig körür sen ölüg sen tirig

Sizik tutma bir kün eşingey yirig” (Arat, 1947, s. 380).

3785. Ölümlüleri görüyorsun, sen de öleceksin; her diri olan, şüphesiz, bir gün toprak ile örtülecektir (Arat, 1959, s. 274).

“Çıgay ma ölür ök yime bay ölür

İki böz iletür kara yir bolur" (Arat, 1947, s. 631). 
6374. Fakir de ölür, zengin de; bunların ikisinin de götürecekleri şey ancak bir kefenden ibarettir ve nihayet kara toprak olur (Arat, 1959, s. 457).

Yaşam ve ölüm gibi konulara değinen Yusuf Has Hacib'e göre geride bırakılan şerefli bir isim her şeyden mühimdir. Geride şerefli bir isim bırakmak için insan iyilik yapmalıdır:

"Tirig ölgü ahır töşengi yirig

Kişi ölse edgun kör atı tirig”(Arat, 1947, s. 39).

237. Her yaşayan er-geç ölecek ve topraga düşecektir; insan iyi nam ile ölürse, adl yaşar (Arat, 1959, s. 28).

"Atı edgü bolmış atanmış akı

Akı ölse atı tirig tip ukl” (Arat, 1947, s. 41).

257. Iyi ad kazanmış, cömertlik ile şöhret bulmuştur; bil ki cömert insan ölse bile, onun adı yaşar (Arat, 1959, s. 29).

"Ne kutlug kut ol erke edgü atı

Bu edgü atı bardı mengü kut” (Arat, 1947, s. 59).

456. Iyi ad insan için ne kadar mübarek bir saadettir; onun bu iyi adı ve saadeti ebedi kaldı (Arat, 1959, s. 43).

"Yana aydl ilig meselde kelir

Uruglug kişi ölse urgı kalır” (Arat, 1947, s. 179).

1623. Hükümdar devam etti:-Şöyle bir mesel vardır, asil insan ölse da his oyu kalır - dedi (Arat, 1959, s. 125).

"Ísiz edgüler ölse toprak bolur

Neçe bolsa toprak kör atı kalır” (Arat, 1947, s. 164).

I790. Iyi veya kötü, ölünce, hep toprak olur; fakat ne kadar toprak olsalar bile, adlarl kalır (Arat, 1959, s. 197).

"Kalır dünya ahır toguglı ölür

İsiz edgü erse kör atı kalur” (Arat, 1947, s. 523).

5255. Dünya kalır, doğan nihayet ölür; insandan kalan ancak iyi veya kötü addır (Arat, 1959, s. 378).

Kırgızcada da zenginliğin geçici olduğuna dair çok sayıda atasözü ve deyimler mevcuttur:

Baylık - murat emes, coktuk - uyat emes (Zenginlik bir amaç değil, yoksulluk da utanç değildir).

Baylık koldun kiri, cuusan ketet (Zenginlik ellerdeki kirdir, yıkarsan geçecektir).

Acal kelse, altın taktan payda cok (Ecel gelirse, altın taht bile kurtaramaz). 
Bayligın bolboso da, barkın bolsun (Dünyan olmazsa da namusun olsun).

\section{2. Dil, Emek, Eğitim, Bilgi}

Yusuf Has Hacib eserinde dilin faydası ile zararlarından bahseder:

"Kişig til ă̆ırlar bulur kut kişi

Kişig til uçuzlar barır er başı” (Arat, 1947, s. 33).

163. Insanı dil klymetlendirir ve insan onunla saadet bulur, Insanı dil kıymetten düşürür ve insanın dili yüzünden başı gider (Arat, 1959, s. 23).

“Öküş sözleme söz birer sözle az

Tümen söz tügünin bu bir sözde yaz” (Arat, 1947, s. 34).

172. Insan söz ile yükseldi ve sultan oldu; çok söz başı, gölge gibi, yere serdi (Arat, 1959, s. 24).

"Til asgı telim bar yası ma öküş Ara ögdilür til ara ming söküş” (Arat, 1947, s. 34).

177. Dilin faydası çok olduğu gibi, zararı da çoktur; dil bâzan öğülür, bâzan da çok sögülür (Arat, 1959, s. 24).

"Sözüg sözlemese sanga kul bolur

Kall sözlese sen sini kul kılur” (Arat, 1947, s. 191).

3880. Sözü söylemezsen o sana kul olur, eğer söylersen o seni kendisine kul eder (Arat, 1959, s. 281).

$\mathrm{Bu}$ tür dilin faydası ve zararlarını Kırgız atasözlerinde de görebiliriz.

Önör aldl - klzıl til (Beceriden önce güzel konuşma gelir).

Oozunan kulagan turbayt, butunan kulagan turat (Yanlış konuşan düzelmez, yanlış basan düzelir).

Kıllı̧ carası bütöt, til carası bütpöyt (Kılıç yarası iyileşir ama söz yarası iyileşmez). gibidir).

Oozdon çıkkan söz - koldon uçkan kuş (Ağızdan çıkan söz, elden uçan kuş

Söz atası - ır, söz katasl - çır (Söz atası türkü, söz hatası kavgadır).

Sözün klska bolsun (Sözün kısa olsun); Sözün ölgönçö özün öl (Sözün ölmektense kendin öl.) vb.

Bununla birlikte Yusuf Has Hacib kendi eserinde çalışmanın faydalarından söz etmektedir. Yazar başarıya ulaşmak isteyenlere erken kalkmayı, işleri zamanında bitirmeyi ve tembelliği yenmeyi önermektedir: 
“Negü ekse yirke yana ol önür

Negü birse evre anı ok alur” (Arat, 1947, s. 156).

1394. Yere ne ekilirse, yine o biter; ne verilirse, karşılığında aynı şey alınır (Arat, 1959, s. 109).

"Ivme kılmış işler neçe yig bolur

Ive yise aş suv neçe ig bolur” (Arat, 1947, s. 217).

1998. Acele yapılan işler acı olur; acele yemek-içmek yüzünden hastalı gelir (Arat, 1959, s. 151).

“Tapugka irig bolsa erte turup

Köngül til kiçig tutsa kodkı bolup” (Arat, 1947, s. 407).

4039. Erkenden kalkıp, hizmete karşı bulunmalıdır; sözlerinde ve hareketlerinde mütevazı olması lazımdır (Arat, 1959, s. 293).

"Yumuşka irig bolsa yügrü turu

Kulak köz yiti tutsa aşru köru” (Arat, 1947, s. 408).

4040. Her işi sür'atle ve vaktinde yapmall, işine iyice dikkat ederek, gözü ve kulağl tetikte bulunmalıdır (Arat, 1959, s. 293).

"İdi yakşı aymış kılınçı silig

Bilig birle işke yetürmiş elig” (Arat, 1947, s. 413).

4413. Iş̧e bilgi ile el uzatan, temiz kalpli insan çok iyi söylemiş (Arat, 1959, s. 319).

Kırgız dilinde insanların çalışmaya karşı nasıl davranılması gerektiği konusunda çok sayıda atasözü ve deyim kullanılmaktadır:

Aşıım kalsa kalsın, işim kalbasın (Yemek beklesin, iş beklemesin).

Adamdı adam kılgan asıl emgek (İnsanı insan yapan gerçek emektir).

Araket kılsan- bereket (Çaba gösterirsen, iyi sonuçlar alırsın).

Işstegen tişseyt, iştebegen - tişstebeyt (Emeksiz yemek olmaz).

Bügünkündü ertenkige kaltırba (Bugün yapacağını yarına bırakma).

Yusuf Has Hacib’in eserinde aynı zamanda insanın hayatı için eğitim ve bilginin yararları zikredilmektedir.

"Ukuş ol yula teg karangku tüni

Bilig ol yarukluk yaruttı sini” (Arat, 1947, s. 44).

288. Akıl karanlık gecede bir meş'ale gibidir; bilgi seni aydınlatan bir ışıktır (Arat, 1959, s. 32).

"Ukuşun ăgar ol biliğin bedür

Bu iki bile er agırlık körür” (Arat, 1947, s. 44). 


\begin{tabular}{cr} 
ÇÜTAD & Kutadgu Bilig Eserindeki Görgü Kurallarının \\
Aralık 2019 & Kırgız Atasözlerinde Görünümü \\
\hline
\end{tabular}

289. Insan akll ile yükselir, bilgi ile büyür; bu ikisi ile itibar görür (Arat, 1959, s. 32).

"Ukuşa turur bu agırlık itig

Ukuşsuz kişi bir avuçça tetig” (Arat, 1947, s. 45).

297. Bütün bu hürmet ve itibar akll içindir; akılsız adam bir avuç balçık gibidir (Arat, 1959, s. 32).

"Körü barsa yakşı ayır bu sözüg

Ukuşsuz biligsiz bedütmez özüg” (Arat, 1947, s. 45).

298. Dikkat edersen şu söz çok yerinde söylenmiş: akılsız ve bilgisiz kimse kendisini yükseltemez (Arat, 1959, s. 32).

Hakikate giden yolun zorluklar ile dolu olduğunu ve bilginin tükenmezliğini dile getiren büyük düşünür, bilginin sınırı ve dibi olmayan bir deniz olduğunu belirtmektedir. Yazar, bilgiyi denizin dibinde bulunan incilerle kıyaslar. İnsan ise denizin dibinde saklı olan bu "bilgi incilerini" büyük zorluklara katlanarak denizin dibinden bulup getirmesi gerektiğini söylemektedir. Büyük düşünür, insanın bilgi ve eğitim sayesinde başka insanlar arasında onur ve sayg1 kazanabileceğini ileri sürmektedir:

"Kamug edgülükler bilig asgl ol

Bilig birle buld mesel kökke yol” (Arat, 1947, s. 37).

208. Bütün iyilikler bilginin faydasıdır. Bilgi ile göğe dahi yol bulunur (Arat, 1959, s. 26).

"Biliglig çıkarmasa bilgin tilin

Yarutmaz anıng bilgi yatsa yılın” (Arat, 1947, s. 37).

214. Bilgili bilgisini dili ile meydana çıkarmazsa, yıllarca yatsa bile, onun bilgisi muhitini aydınlatmaz (Arat, 1959, s. 27).

"Ajun tutguka er ukuş bilse ked

Budun başguka er bilig bilse ked” (Arat, 1947, s. 38).

224. Dünyayı elde tutmak için, insanın anlayışlı olması ve halkı itaat altına almak için de, bilgili bulunması elzemdir (Arat, 1959, s. 27).

"Negü tir eşitgil biliglig kişi

Ajunda sınayı yetilmiş yaşi”" (Arat, 1947, s. 41).

261. Bilgili ve dünyada tecrübe ile ömrünü geçirmiş olan insan ne der dinle (Arat, 1959, s. 30).

"Ukuşlug kişi kör karısa munar

Ukuş kitti tip hem kalem me tınar” (Arat, 1947, s. 44).

294. Akıllı insan da yaşlanınca bunar, akıl gittiği için kalem de susar (Arat, 1959, s. 32). 
"Ukuş ol sanga edgü andlig adaş

Bilig ol sanga ked bağırsak kadaş” (Arat, 1947, s. 47).

317. Akıl senin için iyi ve yeminli bir dosttur; bilgi senin için çok merhametli bir kardeştir (Arat, 1959, s. 33).

"Bilig klymetini biliglig bilir

Ukuşka ă̆ırlık biligdin kelir” (Arat, 1947, s. 64).

472. Bilginin klymetini bilgili bilir, akla hürmet bilgiden gelir (Arat, 1959, s. 44).

Yukarıda anılan eğitim ve bilginin önemi Kırgız atasözlerinde şu şekilde verilmektedir:

Bilim aluunu beşikten başta (Bilim almayı beşikten başla).

Bilimdüü bolson ozorsun, bilimsiz bolson osolsun (Bilgili olursan herkesin önüne geçersin, cahil olursan hep kaybedersin).

Bilimdüügö düynö carık, bilimsizge - karangı (Bilgiliye dünya aydın, cahile karanlıktır).

Bilimdüü zor, bilimi cok kor (Bilgili adam güçlüdür cahil adam zayıftır).

Bilegi küçtüü birdi clgat, bilimi küçtüü mindi cıgat (Güçlü olan bir kişiyi yener, bilgili olan bin kişiyi yener).

Bilimden ötkön dosun cok, oorudan ötkön kasın cok (Bilimden sadık dost yok, hastalıktan daha güçlü düşman yoktur).

Bilimindi elge bere albasan bekersin (Bilgiyi başka insanlara aktaramazsan hayatın boşa geçti demektir).

Bilgi edinmenin zorlukları ise Kırgız atasözünde şöyle yansıtılmıştır: Bilim aluu iyne menen kuduk kazganday (Bilgi edinmek iğne ile kuyu kazmak gibidir).

\section{3. İyilik ve Kötülük, Sabır, İtidal}

Bunun yanı sıra iyilik ve kötülük konularının da işlendiği söz konusu eserde Yusuf Has Hacib, insanları yalnızca iyi işleri yapmaya, halkına yararlı olmaya, dürüst olmaya, erdemli bir yaşam sürdürmeye ve tüm bunları çocuklara beşikten itibaren öğretmeye çağırmaktadır:

"Yaş ermez bu edgü bu künlük sanğa

Yarın bolga asgınğ bu kün büt munğu” (Arat, 1947, s. 109).

915. İyiliğin sana bugün hiçbir zararı yoktur; fakat bugün inan ki, yarın onun faydasını göreceksin (Arat 1959, s. 77).

“Asıg körnür erse isizlik bu kün

Yarın yas kılur anda ukgll öğ̈̈n” (Arat, 1947, s. 109). 
916. Kötülük bugün faydalı görünse bile, yarın orada bunun zararını görürsün; bunu düşünüp, idrak et (Arat, 1959, s. 77).

"Bu edgü ong ol kör isizlik bu sol

Solungdın tamu ornı ustmah ong ol” (Arat, 1947, s. 109).

917. Iyilik să̆ ve kötülük soldur; senin solunda cehennem vardir; cennet ise, sağda (Arat, 1959, s. 77).

"Taki bir ajunug tutayın tise

Könülik bile tut köngül til özüng” (Arat, 1947, s. 192).

1748. Ahireti kazanmak istersen, özünü, sözünü ve gönlünü daima temiz tut (Arat, 1959, s. 34)

"Tözü halkka könglün bagırsak bolun

Tuçı edgülük kll sen edgü bulun” (Arat, 1947, s. 232).

2160. Bütün halka içten gelen bir merhamet göster; daima iyilik yap ve kendin iyilik bul (Arat, 1959, s. 162).

"Budunka asıg kll bolup kılma yas

Kılınç edgü tutgll isiz yası bas” (Arat, 1947, s. 232).

2161. Halka faydall ol, ona zarar verme; iyi hareket et, kötülerin zararlarını ortadan kaldır (Arat, 1959, s. 162).

“Yayılma köni tur köngül tut köni

Koni iki ajun könilik bulur” (Arat, 1947, s. 556).

5601. Să̆a sola meyletme, doğrudur, gönlünü dürüst tut; doğru olan her iki dünyada doğruluk bulur (Arat, 1959, s. 40).

İyi ve kötü davranış konusunda Kırgız atasözleri ve deyimleri ile yukarıda bahsi geçen fikirlerin arasında ortak noktalar bulunmaktadır.

Cakşı niyet - carım ırıs (İyi niyet, yarım rızıktır).

Cakşı kişi kalaanı kurat, caman kişi kalaanı buzat (İyi insan şehirler kurar, kötü insan ise yok eder).

Cakşı el kamın oyloyt, caman öz kamın oyloyt (İyi insan halkı düşünür, kötü insan yalnızca kendini düşünür) vb.

Yusuf Has Hacib'e göre adalet ve itidal insanlığın en temel özelliklerinden ve insanın kendi amaçlarına ulaşabilmesi için yetiştirilmesi gereken temel ahlaki niteliklerdir. Ancak hırs ile öfke insana yalnızca zarar verir:

"Ukuşlug ked er övke özdin yirat

Biliglig beg er buşma edgü kıl at” (Arat, 1947, s. 46).

322. Ey akıllı iyi yiğit, öfkeyi kendinden uzaklaştır; ey bilgili bey yiğit, hiddetlenme, iyi ad kazan (Arat, 1959, s. 34). 
"Bi iki bile işke yakma ive

Kall yaksa kıldıng tiriglik yava” (Arat, 1947, s. 47).

323. Öfke ve gazap ile işe yaklaşma; eğer yaklaşırsan, ömrü heder edersin (Arat, 1959, s. 34).

"Amulluk kerek erke kilkı onğay

Örüglük kerek begke togsa kün ay” (Arat, 1947, s. 47).

325. Insan sakin ve mülayim tabiatl olmalıdır: güneş ve ay doğması için beye itidal lazımdır (Arat, 1959, s. 34).

"Buşaklık bile erke övke yavuz

Bu iki bile tutçi emger et öz” (Arat, 1947, s. 48).

332. Hiddet ve öfke insan için fenadir; bu ikisinin yüzünden vücut daima eziyet çeker (Arat, 1959, s. 34).

"Bu kutka küvenme ay kut bulguçı

Keligli turur kut yana barguçı” (Arat, 1947, s. 70).

550. Sen bir az sabret, her işin müsait bir zamanı vardır: vakti gelince kapalı kapılar açılır (Arat, 1959, s. 50).

"Kayu işke ivse uzar kiç kalur

İve kılmış işler ökünçlüg bolur” (Arat, 1947, s. 71).

556. Hangi işte acele edilirse, o iş uzar ve gecikir; acele yapılan işler pişmanlık ile neticelenir (Arat, 1959, s. 50).

"Kamug işse ivme serin öz buka

Serimlig kişiler tegir arzuka” (Arat, 1947, s. 148).

1310. Hiç bir işte acele etme, sabırlı ol, kendini tut; sabırl insanlar arzularına erişirler (Arat, 1959, s. 104).

"Serinse kişi öz tilekin tapar

Serip turdaçı er örünğ kuş tutar” (Arat, 1947, s. 149).

1319. Insan sabrederse dileğine kavuşur; sabredip - bekleyen avcı ak kuş tutar (Arat, 1959, s. 105).

Kırgız halkı da bilgelikten çok dürüstlük ve sabır gibi sıfatlara büyük önem vermektedir:

Bilimdüü bolmok onoy, adam bolmok kıyın (Bilgili olmak kolay, adam olmak zordur).

Adam boluu asta-asta, ayban boluu bir pasta (Adam olmak zordur, hayvan olmak kolaydır).

Adamdın adamkerçiliği açuusu kelgende bilinet (İnsanın insanlığı, öfkelendiğinde belli olur). 
Kırgız atasözlerinde söylendiği gibi bir insanın insanlığa sahip olup olmadığı öfkeyi zapt etmede belli olur.

\section{4. Zaman, Aile ve Eğitim, Dost ve Düşman}

Yusuf Has Hacib, zamanın ebedi olmadığını ve hayatın her anına değer verilmesi konusunda öğ̈̈tler vermektedir:

"Katılan yangılma könilik yolın

Yigitlik yava kilma asgin alın” (Arat, 1947, s. 50).

360. Gayret et, doğruluk yolundan şaşma, gençliği heder etme, ondan faydalanmasinı bil (Arat, 1959, s. 36).

"Küsüs tut yigitlik keçer sinde terk

Kaçar bu tiriglik neçe tutsa berk” (Arat, 1947, s. 50).

361. Gençliği aziz tut, çabuk geçer, ne kadar zıhır muhafaza edersenet, bir gün kaçar (Arat, 1959, s. 36).

"Yigitlik negü yıgdı erse manga

Karllk kelip aldı kelgey sanga” (Arat, 1947, s. 52).

372. Gençlik benim için ne topladı ise, ihtiyarlık gelip onları aldl; o sana da gelecektir (Arat, 1959, s. 37).

Kırgızlar zamanın faniliğini uçan kuş ile kıyaslamaktadırlar. Ubakıt-uçkan kuş (Zaman uçan kuş gibidir). Kırgız atasözlerinde ve deyimlerinde, yaşamın faniliği "bugün ve yarın" olarak nitelendirilerek:

Bügün körgön erten cok (Bugün var olan yarın yok);

Bügün konok, erten comok (Bugün misafir olan, yarın masal olur);

Caşçıllk - caydın camgır ötkünü (Gençlik yaz yağmuru gibidir);

Caşında caman colgo baspagın, adamdık sapatındı saktagın (Gençken kötü yola sapma, insanlık sıfatını koru);

Caşında bersin meenetti, karıganda bersin döölöttü (Gençliğinde zahmet versin, yaşlanınca mutluluk versin).

Yusuf Has Hacib bunların yanı sıra eserinde çocuğun ğitimi ve onu yetiştirme konusunu özellikle önemsemiştir. Yazara göre çocukların doğru yetiştirilmesi, anne ve babanın üstlendiği en önemli vazifedir.

"Kiçig oglanıg kör ukuşka ulam

Yaş1 yetmeginçe yorımaz kılam” (Arat, 1947, s. 44).

293. Küçük çocuğa bak, ona akıl ulaşacaktır. Fakat yaşı gelmedikçe kalemler yürümez (Arat, 1959, s. 32). 
"Ata emgeki bolsa oglı öze

Ol oglı bilir ötrü kılk yang tüze” (Arat, 1947, s. 139).

1218. Baba oğlunun yetişmesi için emek sarf ederse, oğlu o terbiye altında, iyi olarak yetişebilir (Arat, 1959, s. 98).

"Kısa tutsa oglın kör edgü bolur

Atas1 anas1 yarungu bolur" (Arat, 1947, s. 139).

1219. Baba çocuğunu sıkı bir terbiye altında yetiştirirse, annesi ve babası bundan dolayı mutluluk duyar (Arat, 1959, s. 98).

"Ogul kız isiz bolsa kılkı yangı

Ol isiz ata kıldı 1dt1 ong1” (Arat, 1947, s. 139).

1225. Çocuklartn tavrı, hareketi kötü ise, o kötülü̈̆̈̈ baba yapmıștrr; çocuğu iyi olmaktan mahrum eden odur (Arat, 1959, s. 98).

"Ogul kız sebebi ata ol ana

Kılınç artasa ya itilse yana” (Arat, 1947, s. 166).

1486. Çocukların iyi veya kötü olmalarına anne ve babaları sebep olur (Arat, 1959, s. 115).

"Ayama ogul kızka berge yitür

Ogul kızka berge bilig ögretür” (Arat, 1947, s. 166).

1494. Gerekirse, oğula kiza acımadan dayak at; dayak oğula kıza bilgi öğretir (Arat, 1959, s. 116).

"Küninge tengedür turu öglenür Negüni tilese bilür ögrenür” (Arat, 1947, s. 199).

1819. $O$ günden güne gelişir, gittikçe akl tekâmül eder ve her istediğini ögrenir, bilir (Arat, 1959, s. 138).

"Yigitlik ödünde yetürgil tapug

Karılık yetilse barır küç kamug” (Arat, 1947, s. 567).

5716. İbadeti gençlik çağında yerine getir, ihtiyarlık gelince insanin kuvveti kalmaz (Arat, 1959, s. 409).

Yusuf Has Hacib aynı zamanda gençlere kendi anne-babası ve yakın akrabalarına hürmet etmenin yanı sıra yakın çevresine, özellikle büyüklere karşı saygılı olmaları, küçüklere sahip çıkmaları gerektiğini ve bunun sayesinde de insanın mutlaka başarıya ulaşacağını söylemiştir.

"Kadaş yak yagukka yakınlık ula

Ulugka kiçigke sevüg bol küle” (Arat, 1947, s. 150).

1327. Kardeş ve akrabaya yakinlı göster; güler yüzle büyüğün ve küçügün gönlünü al (Arat, 1959, s. 105). 
“Atangnı anangn sevindür tapın

Yanut birge tapgung tümen ming ası”” (Arat, 1947, s. 174).

1569. Babanı, anneni hoşnut eyle, onlara hizmet et; bu hizmet karşıllı̆̆ binlerce fayda elde edersin (Arat, 1959, s. 121).

Kırgız atasözleri ve deyimlerinde ailenin eğitim açısından önemi, insanın iyi ve kötü özelliklerinin ailede kazanıldığı görülür: yapar).

Uyadan emne körsö, uçkanda oşonu alat (Yuvanda ne görürse, uçunca onu

Ata tarbiyalagan bala - estüü, ene tarbiyalagan bala - eptüü (Babanın yetiştirdiği çocuk akıllı, annenin yetiştirdiği çocuk ise becerikli olur).

Adamdın caman - cakşısı tuulgandan emes, körgön tarbiyasinan (İnsanın iyisi kötüsü doğuştan ziyade terbiyeden kazanılır).

Tal caş kezinde iyilet (Ağaç yaş iken eğilir).

Bunların dışında Kırgız atasözlerinde namus ve itibarlı ismi korumak için anne-babaya sayg1 duymak gerektiğinden söz edilmektedir:

Ata-enendi stylasan, öz balandan sly körösün (Anne-babaya saygı duyarsan çocuğundan saygı görürsün).

Ata stylagan abiyir tabat (Babaya saygı duyan vicdanlı olur).

Bunun dışında Yusuf Has Hacib kendi eserinde gençlere, dost ve düşmana nasıl davranılması, nasıl arkadaş seçmesi ve kimden sakınması veya kimi takdir etmesi gerektiği konusunda öğütler vermektedir.

"İsizke yaguma yırak tur teze

Yorl edgülük kıl yorlk yol tüze” (Arat, 1947, s. 168).

1508. Kötüye yaklaşma, ondan uzak dur, kaç (Arat, 1959, s. 117).

"Bir ök erse düşman ming ol yaslikl

Mingin dostung erse bir ol azlıkl" (Arat, 1947, s. 422).

4190. Düşman biricik de olsa, onun zararl bindir; binlerce dostun olsa bile, daima bir tanesi eksiktir (Arat 1959, s. 303).

"Agırla sini ol agırlasa çın

Uçuzla uçuzlasa barma yakın” (Arat, 1947, s. 422).

4306. Sana gerçekten hürmet gösterenlere sen de hürmet et, saygısizlart sen de sayma, onlara yakın durma (Arat, 1959, s. 311).

Kırgızcada sözcüksel ve anlamsal bakımdan buna benzer atasözleri de kullanılmaktadır: 
İyilgenge iyilgin başın cerge tiygiçe, kakayganga kakaygın töbön kökkö cetkiçe (Saygı gösterene daha çok saygı göster, kibirli davranana daha büyük kibirle karşıllik ver).

Dosun min bolso da azdik kulat, duşmanın biröö bolso da köptük kılat (Bin dostun olsa bile azdır, bir düşmanın olsa bile çoktur).

Caman menen coldoş bolson kalarsin uyatka, cakşı menen coldoş bolson cetersin muratka (Kötü insan ile dost olursan rezil olursun, iyi insan ile dost olursan muradına erişirsin).

\section{SONUÇ}

Yusuf Has Hacib'in ölümsüz eseri olan Kutadgu Bilig, günümüzde de farklı bilim dallarını temsil eden çeşitli bilim adamlarının ilgisini çekmektedir. Zira bu eser tarih, dil bilimi, etnopsikoloji, kültür bilimi vb. konularının incelenmesi açısından büyük önem arz etmektedir. Bu makalede Kutadgu Bilig ve Kırgız atasözleri ve deyimlerindeki görgü kurallarının karşılaştırılmasına yönelik bir girişimde bulunulmuştur.

Kutadgu Bilig Türk halklarının ilk klasik eserlerinden biridir (Malov, 1951). Söz konusu eserde insani değerleri esas alan ortak Türk felsefesi yansıtılmaktadır. Yusuf Has Hacib eserinde insanları manevi ve ahlaki açıdan arınmaya, birlik ve beraberliğe, bilgi edinmeye, sabırlı olmaya ve aile geleneklerine saygı duymaya çağırmaktadır. Bu eser, gençlere öğüt veren, yol gösteren Türk dünyasının büyük bir mirasıdır. Türk halk biliminde önemli bir yere sahip olan Kırgız atasözleri, Kutadgu Bilig'de daha çok önem verilen görgü kurallarıyla benzerlik göstermektedir. $\mathrm{Bu}$ da Yusuf Has Hacib’in büyük eseri olan Kutadgu Bilig'in sadece Kırgızların değil tüm Türk halklarının ahlaki bakış açısı ile ulusal benliğinin oluşmasını önemli ölçüde etkilediğini bir kez daha kanıtlamaktadır.

\section{KAYNAKÇA}

Aliev, A. (2016). Vostochniy renessans i yego rol v istorikokulturnom razvitii Kyrgyzstana i sopredelnyh territoriy (X v.pervayatret XVI v.). yayımlanmamış doktora tezi. Oş Devlet Üniversitesi. http://arabaev.kg/dt.kg/uploads/Aliev\%20diss.pdf

Arat, R. R. (1947). Yusuf Has Hacib Kutadgu Bilig I - metin. İstanbul: Milli Eğitim Basımevi. https://www.twirpx.com/file/1857154/

Arat, R. R. (1959). Yusuf Has Hacib Kutadgu Bilig II - tercüme. Ankara: Türk Tarih Kurumu Yayınları. 
http://aton.ttu.edu/pdf/Kutadgu_Bilig_Vol_2_Part_1, 2, 3, 4, 5.pdf

Ibragimov, M. (2005). Kırgız makal-lakap, uçkul sözdörü. Karabalta: SALAM, $500 \mathrm{~b}$.

İvanova, L. F. (2003). Gumanistiçeskaya narodnaya pedagogika kak osnova hudojestvenno didaktiçeskih proizvedeniy tyurkotatarskih mısliteley srednevekovya. yayımlanmamış doktora tezi. Kazan Devlet Pedagoji Üniversitesi.

https://www.dissercat.com/content/gumanisticheskayanarodnaya-pedagogika-kak-osnova-khudozhestvennodidakticheskikh-proizveden

Jamal, G. ve Kafkasyalı, M. S. (2016). Kutadgu Bilig araştırmaları tarihi. Ankara.

https://ytbweb1.blob.core.windows.net/files/resimler/books/Kutad gu-Bilig-Turkce.pdf

Kakeev, A. (2012). Istoriya filosofskoy nauki v Kirgizstane: Uchebnik dla vuzov. Bishkek: KRSU, 290.

Kozubekov,T. (1993). Kuttuu bilim: Dastan. Bayırkı türk tilinen kotor. Moskva: NIK, 496.

Malov, S. Y. (1951). Pamyatniki drevnetyurkskoy pismennosti. M.- L.: İzd-vo AN SSSR, 451.

Mukasov, S. (2000). Istoricheskaya dinamika sotsialno-filosofskoy mysli kyrgyzskogo naroda (do nachala xx veka). yayımlanmamış doktora tezi. Kırgız Cumhuriyeti Ulusal Bilimler Akademisi. http://cheloveknauka.com/istoricheskaya-dinamika-sotsialnofilosofskoy-mysli-kyrgyzskogo-naroda-do-nachala-xx-veka

Sıdıkova, Ç. T. (2016). Drevnetyurkskiye eticheskiye idei v Kırgızskih poslovitsah i pogovorkah. Izvestiya Kırgizstana Dergisi (№9), Bishkek, 180-182.

Ter-Minasova, S. G. (2000). Yazyk i mejkulturnaya kommunikatsiya. Moskva: Slovo, 264.

Toktonalıv, K. (2016). Kutuu bilim dastanı - uluu muras. Obshestvenno-obrazovatelnaya l nauchno-populyarnaya gazeta. http://kutbilim.kg/2016/07/01/kuttuu-bilim-dastanyi-uluu-muras/ 